\title{
Ruch prometejski jako defensywny element polityki bezpieczeństwa II RP w latach 1926-1932
}

\section{Wstęp}

Celem podjętym w artykule jest próba przedstawienia realizacji akcji prometejskiej na wybranych kierunkach współpracy z narodami uzależnionymi od Związku Sowieckiego w związku z aktywnością władz II Rzeczypospolitej w latach 1926-1932, ze szczególnym uwzględnieniem zaangażowania władz wojskowych w tym procesie. Cezurę czasową przyjętą w artykule wyznaczają dwa kluczowe wydarzenia dla historii tego okresu, a zarazem dla dziejów koncepcji prometeizmu. Pierwszym wydarzeniem jest przewrót majowy z 1926 r. oraz dojście do władzy stronników obozu piłsudczykowskiego i sprawowanie rządów w Polsce przez obóz określany popularnie mianem sanacji ${ }^{1}$. Wydarzeniem zamykającym czas objęty analizą jest podpisanie w lipcu 1932 r. polsko-sowieckiego paktu o nieagresji. To ostatnie wydarzenie przyczyniło się nie tylko do ewolucji sytuacji międzynarodowej oraz położenia geopolitycznego II RP, ale również spowodowało powstanie ograniczeń w kwestii finansowania ruchu prometejskiego, przejście działalności

W literaturze przedmiotu podkreśla się, że dojście do władzy obozu piłsudczykowskiego oznaczało wyraźne nasilenie się akcji prometejskiej, co było możliwe w rezultacie przebudowy programu politycznej i wojskowej współpracy z organizacjami emigracyjnymi narodów sprzeciwiających się dominacji Związku Sowieckiego. A. Pepłoński, Wywiad a dyplomacja II Rzeczypospolitej, Toruń 2004, s. 269. Do realizacji akcji prometejskiej zaangażowano zarówno polski rząd, jak i struktury organizacyjne wywiadu wojskowego, Ministerstwo Spraw Zagranicznych oraz Ministerstwo Spraw Wewnętrznych. A. Wszendyrówny, Prometeizm jako narzędzie polskiej polityki zagranicznej wobec ZSRR, s. 7, http://www.muzeum-niepodleglosci.home.pl/konferencja/referaty_/23.pdf (12 III 2017); L. Wyszczelski, Rozpruwanie Rosji. Prometeizm - idea i realizacja, Warszawa 2016, s. 171. W tym samym roku, dwa miesiące przed zamachem majowym, powstał Instytut Wschodni w Warszawie w charakterze instytucji naukowej, która funkcjonowała jako kluczowa komórka w strukturze całego ruchu prometejskiego. Więcej na temat prac tej instytucji zob. M. Kornat, W kręgu ruchu prometejskiego. Związek Zbliżenia Narodów Odrodzonych (1921-1923) i Instytut Wschodni w Warszawie (1925-1939), „Politeja” 2004, nr 2, s. 380-391. 
prometejskiej do głębszej konspiracji², jak również swoisty kryzys koncepcji ruchu prometejskiego w latach $1932-1935^{3}$. Dla potrzeb metodologicznych autor dodaje, że ze względu na istotność niektórych materiałów wykorzystanych w analizie, $\mathrm{w}$ artykule uwzględniono przejawy realizacji ruchu prometejskiego od początku 1926 r. (w tym z miesięcy poprzedzających zamach majowy), aż do końca 1932 r.

Ruch prometejski, zwłaszcza w latach 1926-1932, stanowił koncepcję polityczną o szczególnym znaczeniu dla najwyższych czynników państwowych ${ }^{4}$. Była to koncepcja o charakterze defensywnym z punktu widzenia kreowania bezpieczeństwa narodowego II RP5. Najwyższe organy władzy wykonawczej nadzorowały działania realizowane w ramach ruchu prometejskiego. Strukturom wywiadu wojskowego, na czele z Oddziałem II Sztabu Generalnego (Głównego) Wojska Polskiego, powierzono w tej dziedzinie rolę pomocniczą i wykonawczą ${ }^{6}$. O ile jednak w literaturze naukowej wskazywano dotychczas znacznie częściej na uczestnictwo najwyższych czynników politycznych w realizacji ruchu prometejskiego ${ }^{7}$,

2 Przejście ruchu prometejskiego do głębokiej konspiracji było uwarunkowane przede wszystkim brzmieniem art. 3 polsko-sowieckiego paktu o nieagresji. Zgodnie z tym przepisem: „Każda z Umawiających się Stron obowiązuje się nie brać udziału w żadnych porozumieniach z punktu widzenia agresji jawnie dla drugiej Strony wrogich”. Pakt nieagresji między Rzeczpospolitą Polską a Związkiem Socjalistycznych Republik Rad, podpisany w Moskwie dnia 25 lipca 1932 roku (Dz.U. 1932, nr 115, poz. 951). Przed 1932 r. zarówno polscy, jak i sowieccy politycy, dyplomaci i wojskowi zdawali sobie sprawę z faktu, że działalność ruchu prometejskiego miała jawnie antysowiecki charakter, godząc w ukształtowaną po I wojnie światowej wizję funkcjonowania Związku Sowieckiego. Tuż po podpisaniu paktu o nieagresji aktywne zaangażowanie państwa polskiego we wspieranie ruchu prometejskiego mogłoby zostać odebrane jako przejaw pogwałcenia zawartego w art. 3 wspomnianego paktu brania udziału w działaniach wymierzonych przeciwko drugiej stronie. Podobne stanowisko na ten temat zaprezentował P. Libera, stwierdzając: „Możliwości strony polskiej, która dotąd wspierała bardzo aktywnie front narodów zniewolonych przez ZSRR, zostały znacznie ograniczone". P. Libera, Zarys historii ruchu prometejskiego, [w:] II Rzeczpospolita wobec ruchu prometejskiego, t. 4, red. P. Libera, Warszawa 2013, s. 52.

3 Kryzys ten postępował, mimo prób reform, w drugiej połowie lat 30. XX w., a jednym z wyraźnych powodów takiego stanu rzeczy miał być wzrost tendencji nacjonalistycznych w społeczeństwie polskim. M. Kornat, Ruch prometejski - ważne doświadczenie polityki zagranicznej II Rzeczypospolitej, „Nowa Europa Wschodnia” 2008, nr 2, s. 82.

$4 \quad$ S. Mikulicz, Prometeizm w polityce II Rzeczypospolitej, Warszawa 1971, s. 231.

5 A. Rogozińska, Myśl polityczna obozu piłsudczykowskiego wobec kwestii położenia geopolitycznego i bezpieczeństwa granic II Rzeczpospolitej, „Niepodległość” 2014, t. 63, s. 103.

6 A. Żebrowski, Oddział II Sztabu Generalnego/Głównego Wojska Polskiego uczestnikiem wojny informacyjnej na kierunkach Niemcy i Rosja, [w:] Wywiad wojskowy II Rzeczypospolitej, red. P. Kołakowski, A. Pepłoński, Kraków 2011, s. 369.

$7 \quad$ Przy czym, jak zauważył P. Libera, orientacja polityczna prometeizmu przechodziła ewolucję w poszczególnych okresach jej realizacji w okresie międzywojennym, a akcja prometejska nie była w tym względzie jednolita w latach 1918-1939. Wynikało to chociażby z istotnych zmian na scenie politycznej w Polsce przed i po 1926 r. P. Libera, Polski prometeizm. Jak ewoluowat i jak z nim walczono?, „Pressje” 2010, t. 22-23, s. 89-90. 
o tyle dyskurs prowadzony wokół zaangażowania władz wojskowych, w tym zwłaszcza Oddziału II SG WP, wydaje się interesującym oraz wymagającym zarazem rozwinięcia ${ }^{8}$. Wskazuje się bowiem na ścisłą współpracę naczelnych władz politycznych, z Ministerstwem Spraw Zagranicznych na czele, z Oddziałem II SG WP, a także instytutami naukowo-badawczymi i licznymi środowiskami emigracyjnymi w realizacji akcji prometejskiej ${ }^{9}$.

W związku z powyższym i uwzględniając specjalizację autora w problematyce spraw wywiadowczych okresu międzywojennego, skupiono się przede wszystkim na omówieniu działań wywiadu wojskowego II RP wobec ruchu prometejskiego w latach 1926-1932. Zaangażowanie struktur cywilnych władz II RP w rozwoju działań w ramach akcji prometejskiej potraktowano więc w charakterze uzupełniającym, mając na uwadze jednak dominujący wymiar polityczny prometeizmu.

Przyjęte rozwiązanie metodologiczne w obrębie analizy zjawiska prometeizmu znajduje swoje uzasadnienie w ocenie współczesnych historiografów. Jak zauważa P. Libera, kształtowanie się koncepcji prometeizmu w całym okresie dwudziestolecia międzywojennego można podzielić na pięć głównych, następujących po sobie faz. Pierwszą jest faza kształtowania się samej idei prometejskiej, przypadająca do 1921 r., a upowszechniana w rezultacie współpracy narodów wcześniej pozostających pod zaborem rosyjskim. Drugą jest faza powstania ruchu prometejskiego oraz wykształcania w jego ramach podstawowych idei, przypadająca na lata 1921-1926. Trzecim etapem kształtowania prometeizmu - którym objęto szczegółową analizą badawczą w artykule - jest okres tworzenia struktur ruchu prometejskiego, przypadający na lata 1926-1932. W ramach dwóch ostatnich faz należy pisać o kryzysie prometeizmu z lat 1932-1935 i próbie zreformowania tego ruchu w latach 1936-1939, która jednak nie zakończyła się powodzeniem ${ }^{10}$.

Podobną cezurę czasową można odnaleźć w rozważaniach prezentowanych przez M. Kornata ${ }^{11}$, R. Witaka ${ }^{12}$, L. Wyszczelskiego ${ }^{13}$ i szefa Ekspozytury Nr 2 Oddziału Sztabu Generalnego (od 1928 r. Sztabu Głównego) Wojska Polskiego, E. Charaszkiewicza ${ }^{14}$.

8 Na liczne kwestie zaangażowania wywiadu wojskowego w akcji prometejskiej tyle, że w odniesieniu do lat 1921-1926 oraz w szczególności do kierunku Ukraińskiej Republiki Ludowej, wskazuje w swojej książce J.J. Bruski. Por. J.J. Bruski, Między prometeizmem a Realpolitik. II Rzeczpospolita wobec Ukrainy Sowieckiej 1921-1926, Kraków 2010, s. 106-134 i 275-293.

$9 \quad$ M. Kwiecień, Kilka dokumentów z dziejów ruchu prometejskiego lat drugiej wojny światowej, „Krakowskie Studia z Historii Państwa i Prawa” 2014, vol. 7, nr 2, s. 336.

10 P. Libera, Zarys historii..., op.cit., s. 31-56.

11 M. Kornat, Ruch prometejski..., op.cit., s. 76-86.

12 R. Witak, Tajne wojny służb specjalnych II RP. Działalność Ekspozytury nr 2 Oddziału II Sztabu Głównego WP w latach 30. XX w., Łódź 2014, s. 130-184.

13 L. Wyszczelski, Rozpruwanie Rosji..., op.cit., s. 167-217.

14 E. Charaszkiewicz, Zagadnienie prometejskie (referat uzupetniajacy), 12 luty 1940 r., [w:] Zbiór dokumentów ppłk. Edmunda Charaszkiewicza, oprac. A. Grzywacz, M. Kwiecień, G. Mazur, Kraków 2000, s. 56-80. 
W periodyzacji prometeizmu można wskazać także na - rzadziej podejmowaną w historiografii - swoistą kontynuację refleksji prometejskiej przez część polskich środowisk emigracyjnych w pierwszych latach po zakończeniu II wojny światowej ${ }^{15}$. Odległe od samej idei prometeizmu działania oparte na antysowieckiej współpracy narodów prometejskich z III Rzeszą były podejmowane również w okresie II wojny światowej ${ }^{16}$.

Definicja samego prometeizmu przysporzyła współczesnym historykom wiele problemów konceptualizacyjnych. Zaprezentowane przez wielu autorów i zebrane zbiorczo definicje tego ruchu pokazują, że mianem prometeizmu można traktować ${ }^{17}$ :

1) koncepcję „rozczłonkowania” Rosji, a potem Związku Sowieckiego, w celu urzeczywistnienia prawa narodów uzależnionych od tego państwa do samostanowienia;

2) wielonarodowy ruch polityczny i intelektualny, którego głównymi ośrodkami była działalność polityków i intelektualistów polskich, gruzińskich, ukraińskich, azerskich, tatarskich, południowo-kaukaskich oraz turkiestańskich, gotowych do podjęcia współpracy z państwem polskim przeciwko rosnącym wpływom komunistycznego państwa sowieckiego;

3) antyimperialną i antytotalitarną ideę oraz zorganizowany ruch sprzeciwu narodów uzależnionych od carskiej Rosji przed I wojną światową oraz od Rosji bolszewickiej od 1918 r., a potem od Związku Sowieckiego od 1922 r., wymierzony w wizję imperialistycznego ucisku tych narodów przez Rosję, a potem Związek Sowiecki;

4) politykę oraz strategię działania polskiego wywiadu wojskowego w związ$\mathrm{ku} \mathrm{z}$ operacjami o charakterze antysowieckim prowadzonymi $\mathrm{w}$ ramach realizacji polityki wschodniej ${ }^{18}$.

15 T. Landmann, Prometeizm jako założenie polityczno-ideologiczne w korespondencji Polskiej Grupy Prometeusza w Londynie w pierwszych latach po II wojnie światowej, „Wschodnioznawstwo" 2018, s. 261-277.

16 J. Pisuliński, Prometeizm - problemy i pytania historiograficzne, [w:] Ruch prometejski i walka o przebudowe Europy Wschodniej (1918-1940), red. M. Kornat, Warszawa 2012, s. 91-104.

17 Z. Gasimov, Między Warszawa, Paryżem a Stambułem. Myśli o prometeizmie w ideowej przestrzeni międzywojennej Europy, [w:] Ruch prometejski i walka..., op.cit., s. 331-334.

18 Ta ostatnia definicja wydaje się mieć największą użyteczność z punktu widzenia rozważań podjętych w artykule. Prometeizm może być interpretowany jako pewna strategia działania Oddziału II Sztabu Generalnego (Głównego) Wojska Polskiego, której realizacja przebiegała w oparciu o współpracę z wieloma narodami kaukaskimi, a także z niektórymi państwami. Przy czym w artykule celem jest zbadanie niektórych, przykładowych form takiej aktywności Oddziału II SG WP w latach 1926-1932. Autor zdaje sobie sprawę, że prezentowane przykłady nie wyczerpują katalogu znacznie liczniejszych form organizacyjnych oraz wysiłków dyplomatycznych i wywiadowczych, dzięki którym starano się w krótkim okresie zrealizować główne założenia koncepcji prometeizmu. 
Przyjmując zasadność powyższych definicji, autor artykułu starał się odnieść do tezy, zgodnie z którą: Realizację akcji prometejskiej w latach 1926-1932 można traktować jako ważne działania z punktu widzenia kreowania bezpieczeństwa państwa w defensywnym komponencie polityki bezpieczeństwa II RP. Przejawiało się to w zróżnicowanych przykładach i dotyczyło różnych form aktywności, przedsięwziętych nie tylko przez polskie władze cywilne, ale i wywiad wojskowy.

\section{Polsko-gruzińska współpraca w ramach ruchu prometejskiego}

Prowadzenie akcji prometejskiej przez II RP w latach 1926-1932 nie było na tyle dobrze udokumentowanym procesem, aby móc zrozumieć wszystkie złożone przejawy, przykłady i uwarunkowania realizacji ruchu prometejskiego w tych latach $^{19}$. Zamiast tego, warto skupić się na wybranych przykładach realizacji akcji prometejskiej w kontekście defensywnego komponentu polityki bezpieczeństwa państwa polskiego. Z zachowanych archiwaliów wynika, że proces przebiegał na wielu płaszczyznach. Ważnym kierunkiem współpracy w ramach akcji prometejskiej była Gruzja, włączona siłą do Związku Sowieckiego i w pełni uzależniona politycznie od Moskwy. W lutym 1926 r. Minister Spraw Zagranicznych, Aleksander Skrzyński, zakomunikował Ministrowi Spraw Wojskowych, że za wysoce pożądane uważa utrzymanie w Wojsku Polskim 14 gruzińskich oficerów, głównie w randze generałów i pułkowników, a powodem miały być względy polityczne oraz rozwijanie współpracy między Polakami i Gruzinami wymierzone w osłabianie wpływów Związku Sowieckiego. Szef polskiego MSZ wyraził jednak wątpliwość, aby jego resort stać było na przyjęcie zobowiązań finansowych wiążących się z utrzymaniem gruzińskich oficerów w WP. Zaproponował ujęcie wydatków z tym związanych w budżecie Ministerstwa Spraw Wojskowych, aby uniknąć nadmiernego upolitycznienia opisywanego zagadnienia. Należy dodać, że chodziło o oficerów niezakontraktowanych, których stosunek prawny nie został ostatecznie rozstrzygnięty w rezultacie odmowy decyzją prezydenta zakontraktowania tych oficerów ${ }^{20}$.

19 Jak zauważył P. Libera, braki w dokumentacji są następstwem faktu, zgodnie z którym duża część działań w ramach akcji prometejskiej była niejawna, a obieg dokumentacji z osiągniętych rezultatów akcji ograniczony. Znaczna część korespondencji nie była przy tym rozsyłana do poszczególnych placówek dyplomatycznych, jak i wywiadowczych, co utrudnia dokładniejsze poznanie złożonych uwarunkowań i ewolucji prometeizmu w analizowanych latach. P. Libera, Ewolucja ruchu prometejskiego w okresie międzywojennym, [w:] Ruch prometejski i walka o przebudowę Europy Wschodniej (1918-1940), red. M. Kornat, Warszawa 2012, s. 221. Pismo ministra spraw zagranicznych, Aleksandra Skrzyńskiego do Ministra Spraw Wojskowych w sprawie oficerów gruzińskich w Wojsku Polskim z dnia 11 lutego 1926 roku, AAN, Ministerstwo Spraw Zagranicznych, sygn. 6687. 
Sprawa oficerów gruzińskich w WP powróciła w marcu 1926 r. przy okazji pisma szefa Sztabu Generalnego WP, Edmunda Kesslera, do Ministra Skarbu, Jerzego Zdziechowskiego. Nadawca zauważył, że wspomnianych wcześniej 14 gruzińskich oficerów pełni rolę „kierowniczych jednostek emigracji gruzińskiej w Polsce" ${ }^{21}$, co miało stanowić dostateczny argument przesądzający o tym, aby precyzyjniej uregulować status tych osób przebywających w Polsce. W piśmie pojawił się również argument, że Polacy powinni zrewanżować się Gruzinom za ich pomoc okazaną w 1918 r. w momencie tworzenia polskich oddziałów wojskowych na Kaukazie. Do 1921 r. łączna suma pomocy finansowanej ze strony Gruzji miała wynieść przynajmniej kilkanaście milionów franków szwajcarskich. Dodatkowy argument przesądzający za uregulowaniem statutu gruzińskich oficerów w WP dotyczył ich lojalności, staranności i szczególnej sumienności w pracy na rzecz polskiej armii. W związku z trudnościami finansowymi Sztabu Generalnego WP jego szef zaproponował Ministrowi Skarbu poparcie poglądu o przyznanie dodatkowych kredytów na pokrycie wydatków związanych z obecnością gruzińskich oficerów w WP22.

Minister Skarbu odpowiedział na pismo szefa Sztabu Generalnego WP 28 III 1926 r., wyrażając negatywny stosunek do postulowanej prośby o przyznanie kredytu na pokrycie wydatków związanych z pozostaniem w WP 14 gruzińskich oficerów. Minister Skarbu zaznaczył brak ustawowego uprawnienia, aby udzielić Ministerstwu Spraw Wojskowych takiej pomocy finansowej, a także podkreślił znaczenie odmownej decyzji prezydenta, aby zakontraktować wspomnianych oficerów. Odniósł się także do realizowanej w tym czasie redukcji etatów i wydatków osobowych w WP, która dotyczyła polskich oficerów i personelu cywilnego. Wyraził przekonanie, że możliwość zakontraktowania na stałe gruzińskich oficerów nie może być uzasadniona ${ }^{23}$. Tym samym Minister Skarbu opowiedział się za tym, że nie istnieją podstawy prawne, ani faktyczne, aby móc zatrzymać wspomniane osoby w WP, a struktura Gruzinów w WP nie uległa w tym czasie zmianie $^{24}$. Problematyczną kwestię statusu gruzińskich oficerów w WP rozwiąza-

21 Pismo szefa Sztabu Generalnego, gen. bryg. Edmunda Kesslera, do Ministra Skarbu, Jerzego Zdziechowskiego, z dnia 22 marca 1926 roku w sprawie oficerów gruzińskich, AAN, Ministerstwo Spraw Zagranicznych, sygn. 6687.

22 Wysokość postulowanych kredytów miała opiewać na sumę 115 tys. polskich złotych i być równa rocznym poborom wszystkich 14 gruzińskich oficerów w WP. Ibidem.

23 Pismo ministra skarbu, Jerzego Zdziechowskiego, do szefa Sztabu Generalnego, gen. bryg. Edmunda Kesslera, z dnia 28 marca 1926 roku w sprawie oficerów gruzińskich, AAN, Ministerstwo Spraw Zagranicznych, sygn. 6687.

24 Na koniec 1927 r. sporządzono dokument, w którym zebrano informacje na temat liczby zakontraktowanych oficerów pochodzenia gruzińskiego, azerskiego i kaukaskiego w WP. Jeśli chodzi o Gruzinów, to w tym czasie w szeregach WP pracowało 5 generałów, 8 pułkowników, 6 majorów, 9 kapitanów, 42 poruczników i 2 podporuczników. Azerskich oficerów było z kolei tylko 4 , z czego 3 pułkowników i 1 rotmistrz, tyle samo co Górali Kaukaskich, z których 2 byli kapita- 
no w marcu 1927 r. na mocy decyzji Prezydenta RP w sprawie zakontraktowania oraz nadania im przydziałów ${ }^{25}$.

Impas związany z próbą zakontraktowania dodatkowych oficerów gruzińskich w WP nie przyczynił się do osłabienia podstaw współpracy polsko-gruzińskiej w opisywanych latach w ramach realizacji idei ruchu prometejskiego. W lipcu 1929 r. w Warszawie strony debatowały nad wytycznymi w sprawie działania Gruzińskiej Organizacji Wojskowej na wzór wcześniejszej Polskiej Organizacji Wojskowej. Celem działania organizacji miało być „wyszukanie i wyrobienie wśród emigracji gruzińskiej odpowiedniego elementu, zawsze gotowego walczyć dla odzyskania niepodległości Gruzji, a następnie przerzucenie tej pracy na teren gruziński” ${ }^{26}$. Emigracja gruzińska działała szczególnie prężnie w Polsce i we Francji. Przygotowywanie Gruzinów do destabilizowania Związku Sowieckiego po ich przerzuceniu do Gruzji leżało w interesie II RP, ponieważ mieściło się w ramach realizowanej koncepcji ruchu prometejskiego. Ważnym ośrodkiem łączności między emigracją gruzińską i Polakami a Gruzją, zwłaszcza w regionach przygranicznych ze Związkiem Sowieckim, miała być Turcja ${ }^{27}$.

nami, natomiast 2 podporucznikami. Por. Wykaz oficerów kontraktowych w Wojsku Polskim: Gruzinów, Azerów i Górali Kaukaskich z dnia 9 grudnia 1927 roku, AAN, Attachés wojskowi RP przy rządach państw kapitalistycznych 1919-1939, sygn. A-II/33. Utrzymanie tych osób w WP było motywowane różnymi celami. Jednym $\mathrm{z}$ takich celów było udzielenie przez Polaków pomocy dla kadr wojskowych przyszłej armii Demokratycznej Republiki Gruzińskiej. Równie ważne było uzyskanie przez II RP wpływów na późniejsze tworzenie się armii gruzińskiej, stworzenie ośrodka dywersji na terenie Gruzji na wypadek starcia zbrojnego z Sowietami, a także stworzenie podstaw współpracy dla późniejszego ewentualnego wykorzystania cennych surowców kaukaskich dla polskiego przemysłu wojennego. L. Wyszczelski, Rozpruwanie Rosji..., op.cit., s. 202.

Z. Karpus, W. Rezmer, Mniejszości narodowe i wyznaniowe w siłach zbrojnych Drugiej Rzeczypospolitej 1918-1939, Toruń 2001, s. 184. Dalsze losy podchorążych oraz oficerów gruzińskich w Wojsku Polskim szczegółowo omawiają m.in. Z. Kowalski, W. Materski oraz R. Karabin. Zob. Z. Kowalski, Najliczniejsza mniejszość. Gruzini, Azerowie i inni przedstawiciele narodów Kaukazu w Wojsku Polskim w okresie międzywojennym, [w:] Mniejszości narodowe i wyznaniowe w siłach zbrojnych Drugiej Rzeczypospolitej 1918-1939, red. Z. Karpus, Toruń 2001, s. 177-199; W. Materski, Gruzini - oficerowie kontraktowi Wojska Polskiego, „Pro Georgia” 2008, nr 16, s. 13-29; R. Karabin, Gruzińscy podchorążowie i oficerowie kontraktowi w Wojsku Polskim 1921-1939, „Pro Georgia” 1994, nr 4, s. 23-34.

26 Wizyta gen. Aleksandra Zachariadze w Warszawie dnia 17 lipca 1929 roku. Wytyczne Gruzińskiej Organizacji Wojskowej, [w:] II Rzeczpospolita wobec ruchu prometejskiego..., op.cit., s. $152-154$.

27 Jak zauważa M. Kornat, strona polska starała się wykorzystać potencjał płynący nie tylko ze współpracy z Gruzinami, ale również z Azerami w związku z tym, że w Azerbejdżanie rozumiano potrzebę kooperacji $\mathrm{z}$ Turcją $\mathrm{w}$ celu przeciwstawienia się narastającemu zagrożeniu ze strony Związku Sowieckiego. Polska musiała pogodzić się z brakiem perspektyw na współpracę $\mathrm{w}$ ramach ruchu prometejskiego z Ormianami, ponieważ nie istniała możliwość załagodzenia złych stosunków azersko-ormiańskich i ormiańsko-tureckich w związku z oskarżeniami Armenii o ludobójstwo jej ludności w Imperium Osmańskim z lat 1915-1917. Zob. M. Kornat, Ruch prometejski..., op.cit., s. 78. W ocenie z kolei por. S. Zaćwilichowskiego 
Jednym ze sposobów realizacji interesów polskiego bezpieczeństwa w ramach akcji prometejskiej przy współpracy z Gruzinami miało być przygotowanie gruzińskiej dywersji na kierunek sowiecki. Powyższy kierunek współpracy stanowił kontynuację działań przedsięwziętych jeszcze w okresie bezpośrednio po odzyskaniu niepodległości przez Polskę. Pod kątem współpracy wojskowej polsko-gruzińskiej udało się bowiem stworzyć na Kaukazie szczątkową bazę dywersyjną i wywiadowczą przeciwko Rosji sowieckiej, m.in. dzięki udziałowi Polaków w szkoleniu kadry instruktorskiej dla armii gruzińskiej. Działania tego rodzaju w latach 1926-1932 istotnie rozwinięto ${ }^{28}$.

W 1930 r. opracowano obszerny dokument z przygotowania specjalnej grupy dywersyjnej Gruzinów poddanej szkoleniu od 4 do 20 IV tegoż roku. Kursantów wysłano następnie do Gruzji, co miało być elementem wykorzystania zdobytej wiedzy w praktyce działań na trudnym terenie. Szkolenie i przygotowanie - realizowane przy udziale wykładowców należących do Związku Antybolszewickiego - dotyczyło następujących tematów dywersji przeciwko Związkowi Sowieckiemu w regionie kaukaskim ${ }^{29}$ :

1) zasad organizacji terenu, z którego miała być prowadzona dywersja - na terenie Gruzji ustalono, że w każdym z 16 głównych okręgów miały funkcjonować zespoły osób odpowiedzialnych za dywersję;

2) zasad łączności ukrytej - realizowanych dzięki pracy kurierów, osób piszących raporty, prasy, czy umówionym znakom w mieszkaniach i w terenie;

3) akcji dywersyjnych bez wykorzystania materiałów wybuchowych - po pierwsze dywersji centrali radiostacji, telegrafu, telefonów, wodociągów, elektrowni, a po drugie dywersji na kolei (niszczenie dworców kolejowych, torów, lokomotyw, wykolejanie pociągów itp.);

4) nauki przygotowywania i korzystania z materiałów wybuchowych, a także akcji dywersyjnych $\mathrm{z}$ wykorzystaniem tych materiałów - niszczenia mostów i tunelów, urządzeń portowych, komunikacyjnych, zakładów przemysłowych itp.;

z sierpnia 1930 r., porozumienie z Turcją w sprawie zasadniczych aspektów lansowanej przez II RP idei akcji prometejskiej miało kluczowe znaczenie dla powodzenia tej akcji i w ogóle jej kontynuowania - zwłaszcza na obszarze Kaukazu. Wywiad turecki interesował się działaniami polskiego wywiadu wojskowego i polityków w ramach koncepcji prometeizmu, a w ocenie strony polskiej należało uzyskać zrozumienie dla tej akcji ze strony Turcji, z którą Polskę łączyły wspólne interesy przeciwstawienia się rosnącym wpływom Związku Sowieckiego w regionie kaukaskim. Por. Sprawozdanie por. Stanisława Zaćwilichowskiego z dnia 13 sierpnia 1930 roku z podróży do Stambułu, CAW, Oddział II SG WP, sygn. I.303.4.5710.

28 M. Mądzik, Z historii politycznych stosunków polsko-gruzińskich w latach 1918-1921, [w:] Pro Georgia. Prace i materiały do dziejów stosunków gruzińsko-polskich, red. D. Kolbaja, Warszawa 1991, s. 23.

29 Sprawozdanie kpt. Stefana Nowaczka z wyszkolenia dywersyjnej grupy gruzińskiej [1930], [w:] II Rzeczpospolita wobec ruchu prometejskiego..., op.cit., s. 175-181. 
5) pracy fotograficznej;

6) akcji dywersyjnych z wykorzystaniem środków bakteryjnych oraz bojowych środków chemicznych;

7) akcji dywersyjnych z użyciem krótkiej broni palnej;

8) wyszkolenia wodnego;

9) prowadzenia propagandy, zwłaszcza w prasie, a także służby informacyjnej.

Współpraca polsko-gruzińska w ramach ruchu prometejskiego była w latach 1926-1932 zdeterminowana dodatkowo faktem, że region Kaukazu postrzegano w II RP jako „naturalną bramę wypadową dla polskiej ekspansji politycznej i ekonomicznej do Azji” ${ }^{30}$. W połowie stycznia 1932 r. Zarząd Zrzeszenia Byłych Członków Polskiej Organizacji Wojskowej - Wschód przygotował memoriał, w którym podsumowano ówczesny kształt polsko-gruzińskiej współpracy w ramach ruchu prometejskiego od 1918 r. Podkreślono uznanie przez II RP dla gruzińskiego rządu emigracyjnego w Paryżu i starania w stworzeniu Statutu oraz podstaw działalności Gruzińskiej Organizacji Wojskowej ${ }^{31}$. Z kolei w merytorycznym uzupełnieniu memoriału, wystosowanym do Józefa Piłsudskiego w lutym 1932 r. podkreślono, że współpraca, o której mowa „opierała się w swoim założeniu na gruzińskim ruchu niepodległościowym, dający się wyzyskać dla interesów państwowości polskiej" ${ }^{32}$. I dalej pisano, że realnym rezultatem tej współpracy było „osiągnięcie rzeczywistego zjednoczenia wszystkich odłamów politycznych emigracji gruzińskiej w jednolitym froncie antybolszewickim (...) oraz wszechstronne wyszkolenie w ramach Wojska Polskiego grupy oficerów Gruzinów, która mogłaby w przyszłości stanowić rdzeń armii gruzińskiej”33.

W lutym 1932 r. zaproponowano także reformę współpracy polsko-gruzińskiej w ramach ruchu prometejskiego, kierując się potrzebą uaktualnienia celów tego ruchu i potrzebą wzmocnienia polskiego bezpieczeństwa w obliczu braku układu ze Związkiem Sowieckim o nieagresji ${ }^{34}$. Współpraca miała zostać ukierunkowana na trzy główne płaszczyzny. Pierwszą była kooperacja państwa polskiego z rządem gruzińskim w Paryżu i jego przedstawicielami w II RP, aby pozyskać wartościowe osoby z tej emigracji dla celów polskiej polityki bezpieczeństwa. Drugą płaszczyzną było szkolenie kadry korpusu oficerskiego przyszłej

30 Memoriał Zarządu Zrzeszenia Byłych Członków POW - Wschód KN 3 dla Marszałka Józefa Piłsudskiego z dnia 15 stycznia 1932 roku w sprawie współpracy polsko-gruzińskiej [wraz z 13 załącznikami], AAN, Akta Aleksandry i Józefa Piłsudskich, sygn. I/49.

31 Ibidem.

32 Merytoryczne wyjaśnienia, uzupełniające memoriał Zarządu Zrzeszenia Byłych Członków POW - Wschód KN 3 w sprawie współpracy polsko-gruzińskiej adresowane do Marszałka Józefa Piłsudskiego [luty 1932], AAN, Akta Aleksandry i Józefa Piłsudskich, sygn. I/49.

Ibidem.

Układ taki podpisano dopiero w lipcu 1932 r., co również musiało wpłynąć na kształt polsko-gruzińskiej współpracy w ramach ruchu prometejskiego. Ta problematyka wykracza jednak poza ramy czasowe przyjęte $\mathrm{w}$ niniejszym artykule. 
armii Gruzji w WP, przy nadaniu wszystkim tym oficerom obywatelstwa polskiego. Trzecią płaszczyzną kooperacji miało być nawiązanie stałego oraz bliskiego kontaktu z niepodległościowymi organizacjami na terenie Gruzji i wprowadzenie do tych organizacji członków emigracji gruzińskiej ${ }^{35}$. W listopadzie $1932 \mathrm{r}$. Oddział II SG WP komentował wspólnie z Gruzińskim Centrum Narodowym projekt Paktu Konfederacji Kaukaskiej ${ }^{36}$. Rezultaty tych rozmów były widoczne w kolejnym okresie rozwoju idei prometeizmu, w związku z czym autor zdecydował się ich szczegółowo nie omawiać w ramach podjętych w artykule rozważań.

\section{Kooperacja z Góralami Kaukaskimi, Kozakami, Tatarami krymskimi i emigracją turkiestańską jako sposób realizacji akcji prometejskiej}

Współpraca z Gruzinami, aczkolwiek bardzo ważna do analizy znaczenia ruchu prometejskiego dla bezpieczeństwa II RP, nie była jedynym sposobem na realizację tej idei w ramach polityki zagranicznej państwa polskiego. Próbowano także do współpracy pozyskać przedstawicieli innych narodów szeroko rozumianego regionu kaukaskiego, w szczególności Górali Kaukaskich, Kozaków, Tatarów krymskich oraz przedstawicieli emigracji turkiestańskiej37. Kaukaz stał się regionem większego zainteresowania ze strony polskich służb dyplomatycznych po utworzeniu przez MSZ w lutym 1927 r. Konsulatu Generalnego RP w Tbilisi. Pierwszym konsulem nowo utworzonej placówki został Zbigniew Mostowski ${ }^{38}$. Starano się wykorzystać rezultaty dotychczasowej współpracy z Gruzinami, aby móc dotrzeć także do innych narodów kaukaskich ${ }^{39}$. Analogiczne wysiłki w porównaniu do polskiego MSZ podjął na tym kierunku Oddział II SG WP, bazując na wcześniejszych doświadczeniach z lat 1921-1925 ${ }^{40}$.

Współpraca $\mathrm{z}$ narodami kaukaskimi była bardzo ważnym postulatem w ramach realizacji akcji prometejskiej. Istotnym elementem współpracy były kon-

35 Projekt reformy podstaw współpracy polsko-gruzińskiej uzupełniający memoriał Zarządu Zrzeszenia Byłych Członków POW - Wschód KN 3 adresowany do Marszałka Józefa Piłsudskiego z dnia 16 lutego 1932 roku, AAN, Akta Aleksandry i Józefa Piłsudskich, sygn. I/49.

$36 \quad$ R. Witak, Tajne wojny..., op.cit., s. 164.

37 W. Komar, Emigracja kaukaska w ruchu prometejskim okresu międzywojennego, [w:] Kaukaz w stosunkach międzynarodowych. Przeszłość, teraźniejszość, przyszłość, red. K. Borkowski, P. Olszewski, Piotrków Trybunalski 2008, s. 217-220.

38 Raport Z. Mostowskiego do MSZ z XI 1927, AAN, Ministerstwo Spraw Zagranicznych, sygn. 10218.

39 A. Furier, Kaukaz w dokumentach polskiej służby konsularnej z okresu międzywojennego, Szczecin 2019, s. 91; M. Kruszyński, Kaukaz w polityce MSZ - rola i znaczenie Konsulatu Generalnego RP w Tbilisi w okresie międzywojennym, „Nowy Prometeusz” 2012, nr 2, s. 248.

$40 \quad$ M. Kornat, Ruch prometejski..., op.cit., s. 78-79. 
takty, które nawiązywano z Góralami Kaukaskimi (określanymi w dokumentach polskiego wywiadu także Kaukazczykami). Działania tej grupy etnicznej były obserwowane przez zlokalizowaną w Konstantynopolu polską placówkę wywiadowczą Konspol, która przekazywała komunikaty Oddziałowi II SG WP. W jednym z komunikatów z września 1927 r. poruszono sprawę przyznania Góralom Kaukaskim paszportów polskich przez polski konsulat w Turcji celem ułatwienia przedostawania się takich osób do Polski z cennymi dla Oddziału II SG WP informacjami. Dostrzeżono, że władze tureckie stosują restrykcyjny model kontroli granic, dokonując aresztowań i cofając osoby próbujące przekroczyć turecką granicę, podejrzewając ich o współpracę z białymi Rosjanami na obszarze Turcji ${ }^{41}$. Rekrutowanie na potrzeby polskiego wywiadu agentów wśród Górali Kaukaskich i otrzymywanie informacji tą drogą było utrudnione i w opisywanym czasie stanowiło stosunkowo mało efektywny sposób realizacji akcji prometejskiej ${ }^{42}$.

W drugiej połowie lat 20. i na początku lat 30. Oddział II SG WP starał się wspierać działalność, ważnej dla realizacji idei prometeizmu, emigracyjnej organizacji kaukaskiej w postaci Komitetu Niepodległości Kaukazu ${ }^{43}$. W maju 1930 r. w polskiej stolicy odbyło się, przy udziale członków ze strony polskiej, posiedzenie Komitetu. Polacy uzależnili jakiekolwiek wsparcie finansowe dla Komitetu od wyników jego prac przy rozpoznaniu stanowisk poszczególnych państw obcych w kwestii niepodległości narodów kaukaskich od Związku Sowieckiego, a także przedstawienia stronie polskiej możliwości działania Komitetu na konkretnych terenach w regionie Kaukazu. Członkom Komitetu polecono kontaktować się z Polakami za pośrednictwem agencji telegraficznej Express, której działalność informacyjną oraz propagandową oceniono bardzo dobrze $e^{44}$.

W październiku 1930 r. powstały ważne wytyczne w dziedzinie współpracy z Komitetem Niepodległości Kaukazu, które przekazano posłowi RP w Teheranie, Stanisławowi Hemplowi. Współpraca pomiędzy Polską a tym ugrupowaniem

$41 \quad$ List szefa Placówki Wywiadowczej Konspol w Konstantynopolu, kpt. Mateusza Iżyckiego, do szefa Oddziału II Sztabu Generalnego, płk. Tadeusza Schaetzla, z dnia 13 września 1927 roku w sprawie paszportów polskich dla Kaukazczyków, AAN, Attachés wojskowi RP przy rządach państw kapitalistycznych 1919-1939, sygn. A-II/33.

42 Pomimo tego Górale Kaukascy - obok Gruzinów, Ukraińców i Azerów - stanowili tę grupę, której członkowie byli szkoleni na oficerów kontraktowych dla WP, gdyż w ocenie Ekspozytury Nr 2 Oddziału II SG WP przedstawiali wartość dla akcji prometejskiej przeciwko Sowietom. Zob. A. Wszendyrówny, Prometeizm..., op.cit., s. 17-18.

43 Komitet powstał w 1926 r., a jego utworzenie ocenia się w literaturze jako „sygnał zdynamizowania działań ruchu prometejskiego" bezpośrednio po zamachu majowym. A. Krawcewicz, Ideologiczne podstawy polskiej geopolityki na przykładzie koncepcji prometejskiej, „Zeszyty Naukowe Uniwersytetu Szczecińskiego. Acta Politica” 2014, nr 28, s. 26.

44 Protokół z dnia 27 maja 1930 roku z posiedzenia Komitetu Niepodległości Kaukazu w Warszawie z udziałem przedstawicieli strony polskiej, AAN, Ministerstwo Spraw Zagranicznych, sygn. 6690. 
została zorientowana pomiędzy kontakty z konkretnymi środowiskami kaukaskimi, w tym Azerbejdżańskim Centrum Narodowym, Gruzińskim Centrum Narodowym, czy Ludową Partią Górali Kaukaskich. Z kręgu zainteresowania polskiego wywiadu wykluczono ugrupowania ormiańskie, ponieważ dostrzeżono ich prosowiecką orientację. Do celów zadań polskich placówek prowadzących działania na obszarze Kaukazu należało: rozpoznanie stanowiska perskiego wobec akcji prometejskiej, obserwowanie rozwoju sytuacji wśród narodów kaukaskich, pośredniczenie w przesyłaniu korespondencji do Oddziału II SG WP, jak również pośredniczenie $\mathrm{w}$ przesyłaniu środków finansowych dla prometejskich organizacji kaukaskich bez angażowania sum własnych. Ważna miała być „opieka moralna nad przedstawicielami organizacji [kaukaskich] i ostrożne w miarę możliwości parowanie żądań placówek sowieckich do wysiedlania ich z terenu" ${ }^{\prime 2}$.

W latach 1926-1932 Oddział II SG WP zainteresował się możliwością kontaktów z ukraińską organizacją Wolnego Kozactwa, która aktywnie zwalczała wpływy bolszewickie już od zakończenia I wojny światowej. W drugiej połowie lat 20. Sowieci przystąpili do propagandowej kontrofensywy, szerząc wśród kozackiej grupy etnicznej broszury i rozmaite druki komunistyczne, występujące przeciwko Wolnemu Kozactwu. W grudniu 1928 r. reprezentujący stronnictwo gen. Bykadorow zwrócił się do konsulatu RP w Pradze z propozycją współpracy z Polską, poprzez utworzenie w II RP oddziału Wolnego Kozactwa. Oddział II SG WP uzyskał informacje na temat budżetu organizacji na 1929 r., mogąc sobie uświadomić, jakimi możliwościami ona dysponuje przeciwko Sowietom. Kozacy poprosili jednocześnie o dotacje $\mathrm{w}$ formie kredytu ${ }^{46}$.

Polski wywiad wojskowy realizując akcję prometejską starał się dotrzeć do Tatarów krymskich, reprezentowanych przez Dżafera Sejdameta. Ów przywódca przekazywał Polakom informacje na temat działań dyplomatycznych czynionych przez Turcję, Królestwa Włoch i Rumunii w sprawach kaukaskich, zwłaszcza wo-

45 Instrukcja Charlesa Lorence’a [Stanisława Zaćwilichowskiego] dla Stanisława Hempla, posła RP w Teheranie, z dnia 21 października 1930 roku w sprawie współpracy z Komitetem Niepodległości Kaukazu, CAW, Oddział II SG WP, sygn. I.303.4.5463. Jak wykazuje M. Kornat, Oddział II SG WP popierał w tym czasie również działania w regionie Kaukazu, których rezultatem miało być utworzenie tzw. Konfederacji Kaukaskiej. Por. M. Kornat, Idea prometejska a polska polityka zagraniczna (1921-1939/1940), [w:] Ruch prometejski i walka..., op.cit., s. 65. Pomysł przewidywał powołanie odrębnego państwa dla wszystkich narodów kaukaskich, z którymi państwo polskie próbowało nawiązać współpracę w ramach akcji prometejskiej. Podobny pomysł próbowano wcielić w życie bezpośrednio po upadku caratu, kiedy powstała Federacja Zakaukaska, mimo że twór ten nie oparł się ofensywie bolszewickiej i podziałom wewnątrz narodów, które go tworzyły. Por. Kraj Zakaukaski w relacjach dyplomatów II Rzeczypospolitej, oprac. A. Furier, Warszawa 1999, s. 50-53.

46 Pismo pracownika konsulatu RP w Pradze, Tadeusza Lubaczewskiego, do szefa Oddziału II Sztabu Generalnego, płk. Tadeusza Schaetzla, z dnia 7 grudnia 1928 roku w sprawie sytuacji wśród emigracji kozackiej, CAW, Oddział II SG WP, sygn. I.303.4.5430. 
bec sprawy ukraińskiej i tatarskiej. Włosi mieli porozumieć się z Turcją i ustalić podział wpływów na tzw. zony, przy czym cały obszar azjatyckiego Kaukazu miał przypaść Turcji ${ }^{47}$. Utrzymywano również korespondencję między szefem Oddziału II SG WP, Tadeuszem Schaetzlem, a ideowym przywódcą Tatarów krymskich w sprawach potrzeby uregulowania przyszłych stosunków ukraińsko-tatarskich oraz statusu niepodległego Krymu w przypadku oderwania od Związku Sowieckiego ${ }^{48}$. Przywódca ruchu niepodległościowego Tatarów krymskich korespondował zresztą nie tylko z przedstawicielami „Dwójki”, ale już od początku lat 20. również z Józefem Piłsudskim. Jednym z ważniejszych tematów poruszanych w depeszach między Sejdametem a Piłsudskim pozostawała kwestia niepodległości Krymu z ewentualnym objęciem przez Polskę międzynarodowego mandatu nad tym terytorium ${ }^{49}$. Polakom zależało na zbliżeniu środowiska ukraińskiego z Tatarami krymskimi, co było jednym z uwarunkowań wzmocnienia znaczenia ruchu prometejskiego nie tylko w latach 1926-1932, ale również w poprzedzającym okresie. Czynnikiem godzącym w skuteczność działań polskich dyplomatów i wojskowych był jednak fakt, że Ukraina konsekwentnie nie godziła się na niepodległość Krymu, zamiast tego proponując daleko posuniętą autonomię i ochronę praw mniejszości Tatarów krymskich w ramach włączenia Krymu do Ukrainy po rozpadzie integralności terytorialnej Związku Sowieckiego ${ }^{50}$. Przełomu nie przyniosło wspólne porozumienie ukraińsko-tatarskie z grudnia 1929 r., gdzie zaprezentowano dwa alternatywne modele stosunków wewnętrznych w Republice Krymu po jej ewentualnym oderwaniu od Związku Sowieckiego ${ }^{51}$.

47 Pismo kierownika Placówki Wywiadowczej L3 w Konstantynopolu do kierownika Referatu B1. Oddziału II Sztabu Generalnego z dnia 26 kwietnia 1929 roku na temat informacji otrzymanych od Dżafera Sejdameta, CAW, Oddział II SG WP, sygn. I.303.4.1996. Nie tylko Polsce zależało, w związku z przywołanym dokumentem, na monitorowaniu sytuacji narodowościowej w regionie kaukaskim w dobie rosnących wpływów Związku Sowieckiego na tym obszarze. Informacje przekazywane przez Dżafera Sejdameta - mimo że trudno poddać je jednoznacznej ocenie z punktu widzenia użyteczności dla Oddziału II SG WP w perspektywie bezpieczeństwa II RP - pozwalały stronie polskiej przyjąć szersze spojrzenie na międzynarodowy kontekst realizacji idei prometejskiej.

List Dżafera Sejdameta do płk. Tadeusza Schaetzla z dnia 24 stycznia 1930 roku o wyniku rozmów z ministrem spraw zagranicznych Ukraińskiej Republiki Ludowej, Aleksandrem Szulkinem w sprawie stosunków ukraińsko-tatarskich i uznania niepodległości Krymu, CAW, Oddział II SG WP, sygn. I.303.4.5389.

49 P. Libera, Depesze Dżafera Sejdameta do Ligi Narodów i do Marszałka Piłsudskiego w sprawie objęcia przez Polskę mandatu nad Krymem z komentarzem P. Libery, „Nowy Prometeusz” 2012, nr 2, s. 317-322.

50 W. Komar, Stosunki polityczne Ukraińców i Tatarów krymskich w okresie międzywojennym, „Nowy Prometeusz” 2012, nr 2, s. 192.

51 Porozumienie ukraińsko-tatarskie z dnia 17 grudnia 1929 roku, CAW, Oddział II SG WP, sygn. I.303.4.5460. 
W ocenie polskiego wywiadu wojskowego przedstawiciele emigracji turkiestańskiej przedstawiali pewną wartość dla powodzenia akcji prometejskiej ${ }^{52}$. Strona polska prowadziła rozmowy z kierownikiem Niepodległościowej Organizacji Turkiestańskiej, Mustafą Czokajewem ${ }^{53}$. Ustalono, że Ekspozytura Nr 2 Oddziału II SG WP będzie przyznawać organowi prasowemu tej organizacji, gazecie „Yach Turkistan”, comiesięczne subsydia, z kolei polskie MSZ subsydiowało funkcjonowanie wydawnictwa „Yeni Turkistan”. Polacy zdecydowali się ponadto przyjąć do Szkoły Podchorążych Turkiestańczyków w charakterze kandydatów, którzy wcześniej byli kierowani na obowiązkowe kursy nauki języka polskiego, celem odpowiedniego kształcenia i przeszkolenia na potrzeby późniejszej pracy prometejskiej. Strona polska nawiązała stałą współpracę informacyjną z M. Czokajewem za pośrednictwem związanej z ruchem prometejskim i utworzonej już w 1925 r., polskiej agencji telegraficznej Express. Kierownik Niepodległościowej Organizacji Turkiestańskiej wysyłał w ten sposób do Polski komunikaty na temat sytuacji z regionu Turkiestanu, m.in. szczególnie działań realizowanych przez Sowietów ${ }^{54}$.

\section{Polska i Ukraińska Republika Ludowa (URL) a sprawa prometejska}

W aktualnej historiografii brakuje wyczerpujących analiz problematyki relacji II RP i - zmuszonej działać na uchodźstwie w rezultacie działań sowieckich Ukraińskiej Republiki Ludowej w kontekście realizacji koncepcji prometeizmu

52 W ocenie polskiego wywiadu wojskowego licząca przeszło 30 tys. osób mniejszość turkiestańska, zmuszona do emigracji przede wszystkim do Persji i Afganistanu, stanowiła pokaźną liczebnie siłę zdolną do walki o swoje prawa przeciwko działaniom Związku Sowieckiego. Współdziałanie rządu polskiego z emigracyjnymi organizacjami antyradzieckimi $w$ latach 1918-1938, oprac. S. Wroński, „Z dziejów stosunków polsko-radzieckich. Studia i materiały” 1968, t. 3, s. 275.

53 Organizacja ta, choć nie należała do Komitetu Niepodległości Kaukazu, to jednak pozostała organizacją z nim zaprzyjaźnioną i kooperującą. W ocenie Oddziału II SG WP, cele i zadania organizacji były godne poparcia $\mathrm{z}$ inicjatywy polskich placówek zagranicznych działających w regionie kaukaskim. Zob. Instrukcja Charlesa Lorence’a [Stanisława Zaćwilichowskiego] dla Stanisława Hempla, posła RP w Teheranie, z dnia 21 października 1930 roku w sprawie współpracy z Komitetem Niepodległości Kaukazu, CAW, Oddział II SG WP, sygn. I.303.4.5463.

54 Notatka wewnętrzna Ekspozytury Nr 2 z konferencji kpt. Edmunda Charaszkiewicza i por. Stanisława Zaćwilichowskiego z Mustafą Czokajewem z dnia 20 lipca 1930 roku w sprawie działalności emigracji turkiestańskiej, CAW, Oddział II SG WP, sygn. I.303.4.5710. Rezultaty współpracy z emigracją turkiestańską zostały osłabione jednak przez faktyczne działania wywiadowcze Związku Sowieckiego. Sowietom udało się rozbić partyzantkę turkiestańską, którą organizowano w opisywanych latach przy wsparciu w ramach realizacji przez II RP akcji prometejskiej. Więcej na ten temat zob. A. Wszendyrówny, Ekspozytura Nr 2 Oddziału Sztabu Głównego Wojska Polskiego, [w:] Ruch prometejski i walka..., op.cit., s. 207-208. 
w latach 1926-1932. Problematyka ta sytuuje się w ramach bardziej pojemnej tematyki wskazującej na rolę i działania przedstawicieli emigracji ukraińskiej w Polsce w dwudziestoleciu międzywojennym ${ }^{55}$. Co więcej, pojawia się w dokumentach źródłowych i jest bardzo interesującą z punktu widzenia realizacji przez II RP koncepcji prometejskiej. Można spróbować przedstawić przynajmniej kilka źródeł, które traktują o roli URL i Ukraińców w polskiej akcji prometejskiej w analizowanych latach ${ }^{56}$. Jak zauważył J.J. Bruski, na rok 1926 przypada odnowienie współpracy Polski z emigracją ukraińską, co należy traktować jako ważny zwrot w kontekście możliwości realizacji przez II RP akcji prometejskiej ${ }^{57}$. Polsce zależało na zbliżeniu z niepodległościową emigracją ukraińską jako elemencie realizacji koncepcji prometejskiej. Jeszcze w 1926 r., z inicjatywy działacza ruchu prometejskiego, Tadeusza Hołówki ${ }^{58}$, w Paryżu powstało towarzystwo „La Promethee" (Prometeusz). Wydawało ono periodyk o tym samym tytule i grupowało działaczy opowiadających się za zbliżeniem interesów polskich i przedstawicieli emigracji ukraińskiej w kontekście ruchu prometejskiego ${ }^{59}$. Z zachowanych archiwaliów wynika, że założeniu samej organizacji towarzyszył jawnie ideologicznie wydźwięk, co było widoczne w nadaniu „Prometeuszowi” dodatkowej nazwy w postaci Ligi zniewolonych przez Rosję narodów i wymieniając 12 narodów uczestniczących w promowanej przez II RP, akcji prometejskiej ${ }^{60}$.

Z kolei w 1928 r. w Warszawie utworzono Klub „Prometeusz”, który oprócz Ukraińców skupiał również przedstawicieli poszczególnych narodów kaukaskich mających popierać polski ruch prometejski ${ }^{61}$. Przejawem zaangażowania Oddziału II SG WP we wsparcie akcji prometejskiej było udzielanie „Prometeuszowi”

55 E. Wiszka, Emigracja ukraińska w Polsce 1920-1939, Toruń 2004, passim.

W ocenach polskiego wywiadu wojskowego ludność ukraińska na emigracji, którą można było wykorzystać w realizacji koncepcji akcji prometejskiej, liczyła ponad 30 tys. osób, przy czym w tej liczbie osób klasyfikowano także Kozaków. Zauważono jednak, że wśród tej ludności istniała tendencja do rozproszenia się po różnych częściach Europy w celach zarobkowych, co osłabiało potencjał tej grupy jako użytecznej dla akcji prometejskiej. Por. R. Witak, Tajne wojny..., op.cit., s. 148.

57 J.J. Bruski, $Z$ dziejów akcji prometejskiej. Odnowienie wspótpracy Polski z emigracja ukraińską w 1926 roku, [w:] Naród - państwo - Europa Środkowa w XIX i XX wieku, red. A. Patek, R. Wojek, Kraków 2006, s. 147.

58 Tadeusz Hołówko pozostawał w opisywanych latach, aż do swojej śmierci w 1931 r., jednym z najważniejszych działaczy i agitatorów na rzecz zbliżenia Polski z niepodległościową emigracją ukraińską w ramach ruchu prometejskiego. I. Werschler, Federalizm i prometeizm w poglądach oraz działalności Tadeusza Hołówki, „Dzieje Najnowsze” 1982, r. 14, z. 1-4, s. 4.

59 G. Zackiewicz, Polska myśl polityczna wobec systemu radzieckiego 1918-1939, Kraków 2004, s. 191.

60 Ideologia walki ciemiężonych przez Rosję narodów zjednoczonych w organizacji „Prometeusz", CAW, Oddział II SG WP, sygn. I.303.4.5782.

61 B. Światłowski, Prometejska racja stanu, „Poliarchia” 2014, nr 2, s. 163. 
w latach 1928-1930 subwencji w wysokości 500 zł każdego miesiąca, a także pokrywanie kosztów czynszu za zajmowanie lokalu klubowego ${ }^{62}$.

Innymi organizacjami promującymi $w$ analizowanych latach ruch prometejski i koncentrującymi się w szczególnej mierze na kwestii ukraińskiej były Instytut Badań Spraw Narodowościowych, Ukraiński Instytut Naukowy, funkcjonujący od 1926 r. Instytut Wschodni ${ }^{63}$ (centrum polityczne, intelektualne oraz badawcze ruchu prometejskiego ${ }^{64}$, a także działające pod patronatem tego ostatniego Orientalistyczne Koło Młodych ${ }^{65}$.

W sierpniu 1926 r. wydano w formie pisma do Józefa Piłsudskiego tajne memorandum z inicjatywy prezydenta Ukraińskiej Republiki Ludowej na emigracji, Andrieja Liwickiego i ministra spraw wojskowych, Włodzimierza Salskiego, w celu pełniejszej aktywizacji działaczy ukraińskiego ruchu niepodległościowego. Strona ukraińska podniosła kwestię nie tylko politycznego, ale również finansowego wsparcia obozu URL przez II RP ${ }^{66}$. Mając na uwadze wysiłki polskich polityków i wojskowych w dziedzinie ruchu prometejskiego, Ukraińcy samodzielnie wskazali na możliwość zacieśnienia relacji polityczno-wojskowych między URL na uchodźstwie a II RP ${ }^{67}$. W rezultacie zbliżenia między stronami w lutym $1927 \mathrm{r}$. doszło do utworzenia przy sztabie Ministra Spraw Wojskowych w Warszawie tajnego sztabu wojskowego URL, komórki złożonej z oficerów ukraińskich, która funkcjonowała aż do $1939 \mathrm{r}^{68}$. Powyższe działania umożliwiły ponadto zainicjowanie współpracy wojskowej oraz wywiadowczej między sztabami armii II RP i URL ${ }^{69}$.

Zainicjowane działania pozwoliły również na przyjmowanie do służby w WP ukraińskich oficerów kontraktowych, co realizowano od $1928 \mathrm{r}^{70}$. Wskazany przykład zacieśnienia współpracy politycznej oraz wojskowej między II RP i URL stanowił ważne narzędzie realizacji idei prometejskiej przez Polskę w analizowa-

62 G. Mazur, M. Kwiecień, Kilka dokumentów z dziejów ruchu prometejskiego w II Rzeczypospolitej, „Czasy Nowożytne” 2002, nr 12, s. 158.

63 Obszerniej na temat roli Instytutu Wschodniego w akcji prometejskiej zob. I.P. Maj, Działalność Instytutu Wschodniego w Warszawie 1926-1939, Warszawa 2007, passim.

64 A. Grzywacz, G. Mazur, Ruch prometejski w Polsce, „Zeszyty Historyczne” 1994, z. 110, s. 80.

65 Obszerniej na temat tej organizacji zob. P. Libera, Orientalistyczne Koło Młodych przy Instytucie Wschodnim w Warszawie (1929-1939), „Nowy Prometeusz” 2018, nr 12, s. 103-117.

66 S. Mikulicz, Prometeizm..., op.cit., s. 107-108.

67 J.J. Bruski, Między prometeizmem..., op.cit., s. 338-340.

68 J. Pisuliński, Ukrainian diaspora in Polish foreign policy in the interwar period, „Nowa Ukraina” 2011, z. 11, s. 45.

69 Postulaty przedstawione przez stronę polską prezydentowi Ukraińskiej Republiki Ludowej, Andrijowi Liwickiemu i gen. Włodzimierzowi Salskiemu na konferencji dnia 28 VI 1927, CAW, Oddział II SG WP, sygn. I.303.4.5404.

70 Obszerniej na temat zakontraktowania oficerów ukraińskich w WP zob. M. Krotofil, Oficerowie kontraktowi Wojska Polskiego w okresie międzywojennym, „Biuletyn Ukrainoznawczy” 1999, nr 5, s. 21-32. 
nych latach ${ }^{71}$. Z kolei w szerszym kontekście w piśmiennictwie wskazano, że zainicjowany od przełomu lat 1926/1927 nowy kurs wspierania emigracji ukraińskiej pod postacią URL „pozostał do końca okresu międzywojennego trwałym elementem polskiej polityki wschodniej"72.

Po 1926 r. polski MSZ oraz wywiad wojskowy subsydiowały ukraińskie środowiska petlurowskie na czele z Centrum Państwowym URL, które w latach 30. XX w. liczyło sobie w Polsce ok. 12 tys. członków. Zdaniem J. Pisulińskiego, działania te były jednak skoncentrowane w pierwszej kolejności nie tyle na realizacji akcji prometejskiej, co na instrumentalnym wykorzystaniu organizacji do kontroli diaspory ukraińskiej i walki $\mathrm{z}$ antypolską propagandą wśród mniejszości ukraińskiej. Kontrola działań tak rozbudowanej organizacji mogła zarazem być pomocna przy ewentualnej zmianie sytuacji na Ukrainie Sowieckiej i działaniach polskich w tym kierunku polityki wschodniej ${ }^{73}$.

Jednym ze źródeł traktujących o przejawach zbliżenia polsko-ukraińskiego w duchu prometejskim w opisywanych latach jest dokument z czerwca 1927 r., w którym zebrano postulaty polskiego rządu przedstawione na wcześniejszej konferencji prezydentowi URL na emigracji, Andriejowi Liwickiemu i ministrowi spraw wojskowych, Włodzimierzowi Salskiemu. Polacy dostrzegli trudną sytuację wewnętrzną w Związku Sowieckim, która groziła przewrotem, i zachęcali Ukraińców do przyspieszenia prac ukraińskiego ruchu narodowościowego na Kresach Wschodnich. Skrytykowali jednocześnie fakt, że Ukraińcy zrobili niewiele albo nic w takich sprawach, jak kwestie mobilizacyjne czy szkolenie kadr dla potrzeb przyszłej ukraińskiej armii. Utajnienie ukraińskich działań za przyzwoleniem polskich władz na terytorium II RP oceniono jako niedostateczne oraz wymagające większych wysiłków ze strony Sztabu Ukraińskiej Republiki Ludowej. Dostrzeżono, że trudna sytuacja w Związku Radzieckim skutkowała nasileniem działań wywiadowczych przeciwko Polsce oraz działaniom ukraińskich organizacji w II RP. Działania te zostały ukierunkowane na wykrywanie współpracy polsko-ukraińskiej w ramach realizowanej akcji prometejskiej. Z kolei ewentualne demaskowanie przez sowiecki wywiad przykładów tej współpracy oceniono nie tylko jako niekorzystne dla ukraińskiej sprawy narodowej, ale również dla bezpieczeństwa II RP „ze względu na inicjatywę, jaką by się wkładało w ręce Sowietów w wystąpieniach przeciwko Polsce" ${ }^{34}$.

71 R. Potocki, Idea restytucji Ukraińskiej Republiki Ludowej (1920-1939), Lublin 1999, s. 227.

72 J.J. Bruski, J. Pisuliński, Polska dyplomacja wobec emigracji ukraińskiej. Nieznana instrukcja ministra Augusta Zalewskiego z 1926 roku, „Studia z Dziejów Rosji i Europy Środkowo-Wschodniej" 1998, t. 33, s. 161.

73 J. Pisuliński, Centrum Państwowe Ukraińskiej Republiki Ludowej na wychodźstwie w polskiej polityce zagranicznej po 1926 r., „Історичний архів. Наукові студіï” 2010, в. 5, с. 120-123.

74 Postulaty przedstawione przez stronę polską prezydentowi Ukraińskiej Republiki Ludowej, Andrijowi Liwickiemu i gen. Włodzimierzowi Salskiemu na konferencji dnia 28 VI 1927, CAW, Oddział II SG WP, sygn. I.303.4.5404. 
Polacy zarekomendowali zwolnić ze służby tych oficerów w Sztabie Ukraińskiej Republiki Ludowej, którzy z powodu wieku albo stażu wojskowego w dawnych latach nie wykazywali zrozumienia dla sprawy prometejskiej. Zaoferowano pomoc w zabezpieczeniu zasiłku emerytalnego. Zdecydowany postulat strony polskiej dotyczył propozycji skompletowania Sztabu Ukraińskiej Republiki Ludowej przy porozumieniu ze Sztabem Generalnym RP w taki sposób, aby ten pierwszy stał się organem ukraińskiego Ministerstwa Wojny. Jego członkowie mieli zostać pozbawieni możliwości sprawowania funkcji reprezentacyjnych. Strona polska poleciła utworzenie funkcji Inspektora w postaci jednego generała i jego adiutanta, który pełniłby funkcję łącznika między Ministrem Wojny a wojskowymi ośrodkami ukraińskiej emigracji ${ }^{75}$.

W dniu 24 I 1930 r. szef Ekspozytury Nr 2 Oddziału II SG WP, Edmund Charaszkiewicz, otrzymał list od prof. R. Smala-Stockiego, w którym pojawiła się propozycja organizowania w Polskim Radiu ukraińskich audycji propagandowych wymierzonych, w domyśle, w Związek Sowiecki. Autor listu zauważył, że propaganda radiowa odgrywa coraz większą rolę $\mathrm{w}$ walce $\mathrm{z}$ komunizmem, zarówno w Polsce, jak i w regionie kaukaskim oraz na ukraińskich Kresach Wschodnich. Polsko-ukraińska współpraca w sferze szerzenia antysowieckiej propagandy radiowej miała stanowić odpowiedź na rosnący wpływ sowieckofilskich treści głoszonych przez radiostacje w Moskwie, Kijowie oraz Charkowie. Autor listu dostrzegł przy tym bierność polskiej strony w wykorzystaniu radia jako środka walki informacyjnej i całkowite pokrywanie się polskich i ukraińskich interesów polityki narodowej. W liście pojawiła się propozycja, aby w Polskim Radiu udzielono tygodniowo 2 godzin audycji dla odczytów ukraińskich, w których byłyby prezentowane najważniejsze informacje o sytuacji na ziemiach ukraińskich uzależnionych od Związku Sowieckiego. Wykłady radiowe mieli prowadzić profesorowie Uniwersytetu Warszawskiego, Ukraińcy, a także wybitni politycy i uczeni wywodzący się z Ukraińskiej Republiki Ludowej. Tematyka odczytów radiowych miała pokrywać się z zagadnieniami politycznymi, gospodarczymi i społeczno-kulturalnymi w Ukrainie sowieckiej, z kolei w mniejszym stopniu poruszać problemy życia na Wołyniu i w Małopolsce Wschodniej. Zdaniem autora listu: „Nadawanie odczytów ukraińskich przez radio Polskie będzie miało znaczenie i dla wewnętrznej polityki polskiej, gdyż przez to sparaliżuje się propagandę antypolską, prowadzoną przez radiostacje Charkowa i Kijowa"76. Tego rodzaju płaszczyzna współpracy w ramach ruchu prometejskiego miała mieć w związku z powyższym implikacje dla polskiego bezpieczeństwa w warunkach stałego zagrożenia ze strony Związku Sowieckiego.

75 Ibidem.

76 List prof. Romana Smal-Stockiego do kpt. Edmunda Charaszkiewicza w sprawie zorganizowania ukraińskich audycji propagandowych w Radiu Polskim z dnia 24 stycznia 1930 roku, CAW, Oddział II SG WP, sygn. I.303.4.5389. 
Propozycja spotkała się ze zrozumieniem adresata listu, reprezentującego polski wywiad wojskowy. Po konsultacjach ze stroną ukraińską poparto organizowanie w Polskim Radiu tzw. „Chwilek ukraińskich”, których treści miały stanowić „odpowiedzi na radiową propagandę bolszewicką, zwróconą przeciw interesom RP"77. Tyle że audycje ukraińskie miały być prezentowane przez radiostację we Lwowie, a nie w Warszawie. Strona polska przekonała Ukraińców o swojej lojalności w kwestii sprawy kozackiej, opowiadając się za postawą wyczekującą wobec Kozaków i zobowiązując się nie popierać takich interesów różnych ugrupowań tej grupy etnicznej, które mogłyby zostać odebrane przez Ukraińców jako działania na szkodę ukraińskiej sprawy narodowej. Strona polska sformułowała ponadto postulat, że zwróci się do prezydenta Ukraińskiej Republiki Ludowej na emigracji, A. Liwickiego, o wspólne skonsultowanie kwestii związanych z polską pracą prometejską na odcinku kozackim ${ }^{78}$.

Należy też wzmiankować, że od kwietnia 1932 r., Ekspozytura Nr 2 Oddziału II SG WP przyjęła na siebie obowiązek finansowania wypłat stypendiów dla studentów ukraińskich studiujących w Polsce oraz na niektórych uczelniach zagranicznych w ramach współpracy z ukraińskimi organizacjami niepodległościowymi. Środki pochodziły z budżetów Sztabu Głównego oraz Ministerstwa Spraw Zagranicznych, z kolei instytucją pośredniczącą w przekazywaniu środków był Instytut Wschodni w Warszawie (dla studiujących w Polsce) oraz właściwe ośrodki zagraniczne emigracji ukraińskiej (dla studiujących za granicą). Z pomocy organizowanej przez Ekspozyturę Nr 2 korzystali ponadto studenci gruzińscy, turkiestańscy, azerscy oraz wywodzący się z Górali kaukaskich i Tatarów krymskich $^{79}$. Od 1932 r. w Warszawie wydawano też Biuletyn Polsko-Ukraiński, pismo wyrażające ideę pojednania obu tych narodów. Zdaniem ukraińskiego historyka, W. Komara, wydarzenie stanowiło ważny zwrot w realizacji idei prometejskiej $\mathrm{z}$ punktu widzenia zbliżenia polsko-ukraińskiego początku lat $30 . \mathrm{XX} \mathrm{w}^{80}$.

\section{Podsumowanie}

W latach 1926-1932 Oddział II SG WP zaangażował się w popieranie rozwoju akcji prometejskiej w odniesieniu do rozmaitych kierunków współpracy

77 Notatka kpt. Edmunda Charaszkiewicza dla płk. Tadeusza Schaetzla z zebrania polsko-ukraińskiego w sprawie organizacji audycji radiowych ukraińskich i uregulowania stosunków ukraińsko-kozackich z dnia 28 stycznia 1930 roku, CAW, Oddział II SG WP, sygn. I.303.4.5389. Ibidem.

Notatka wewnętrzna Ekspozytury nr 2 z dnia 6 grudnia 1932 roku w sprawie stypendystów z emigracji prometeuszowskiej, CAW, Oddział II SG WP, sygn. I.303.4.5497.

В. Комар, Кониепція прометеїзму в політиці Польщі (1921-1939 рр.), Івано-Франківськ 2011, c. 274-276. 
z narodami objętymi taką akcją. Mogło to stanowić defensywny komponent umacniania systemu bezpieczeństwa narodowego II RP. Jak pisze J.J. Bruski, prometeizm był w tym czasie przede wszystkim "narzędziem obrony" ${ }^{11}$, a nie narzędziem do prowadzenia ofensywnej akcji przeciwko Związkowi Sowieckiemu. Opisywana koncepcja była oryginalnym sposobem prowadzenia nie tylko polityki zagranicznej, ale również działań w sferze wywiadu wojskowego. Dzięki niej włączono do współpracy z Oddziałem II SG WP poszczególne narody kaukaskie narażone na propagandę, agitację oraz zagrożenie agresją ze strony najpierw Rosji bolszewickiej, a od końca 1922 r. - Związku Sowieckiego.

Realizacja koncepcji prometejskiej w oparciu o przedstawione $\mathrm{w}$ artykule przykłady wpisywała się w szerszy kontekst prowadzenia przez państwo polskie działań ukierunkowanych na osłabienie Związku Sowieckiego przy jednoczesnym wsparciu rozwoju ruchów niepodległościowych wybranych nacji uzależnionych od tego państwa. W latach 1926-1932 działania polskiego wywiadu wojskowego pokrywały się z polityczną wizją prometeizmu, kreowaną wówczas przez sanacyjny obóz rządzący. Realizacja założeń ruchu prometejskiego wymagała ponadto istnienia skoordynowanej współpracy zarówno polityków, dyplomatów, jak i oficerów wojskowych. Włączenie Oddziału II SG WP do realizacji tego wymiaru polityki wschodniej pokazywało, jak istotna była to koncepcja dla wzmacniania bezpieczeństwa zewnętrznego II RP w perspektywie zagrożenia ze strony Związku Sowieckiego.

Przedstawione $\mathrm{w}$ artykule argumenty i stanowiska pozwalają rozstrzygnąć jako prawdziwą postawioną wcześniej tezę, zgodnie z którą: Realizację akcji prometejskiej w latach 1926-1932 można traktować jako ważne działania z punktu widzenia kreowania bezpieczeństwa państwa w defensywnym komponencie polityki bezpieczeństwa II RP. Przejawiało się to w zróżnicowanych przykładach i dotyczyło różnych form aktywności, przedsięwziętych nie tylko przez polskie władze cywilne, ale i wywiad wojskowy. Aktywność dotyczyła nawiązywania i rozwijania kontaktów z Gruzinami, Azerami, Góralami Kaukaskimi, Kozakami, Tatarami krymskimi, emigracją turkiestańską, czy też Ukraińcami. Wspólny interes dotyczył osłabienia interesów sowieckich w tej części świata, a z punktu widzenia II RP dalekosiężna akcja prometejska miała przyczynić się do poprawy bezpieczeństwa $\mathrm{w}$ trudnym położeniu geopolitycznym. Uzasadnione jest pisanie o akcji prometejskiej nie tylko jako o politycznym zamierzeniu ówczesnych władz II RP, ale ważne pozostaje również praktyczne wsparcie tej koncepcji w latach 1926-1932 ze strony Oddziału II SG WP jako naczelnej struktury polskiego wywiadu wojskowego.

81 J.J. Bruski, Między prometeizmem..., op.cit., s. 346. 


\section{Abstract \\ Tomasz Landmann \\ Prometheism as a defensive element of security policy of second Polish Republic in 1926-1932}

The article presents examples of the implementation of the Promethean action on selected directions of cooperation with nations dependent on the Soviet Union in connection with the activity of the authorities of the Second Republic of Poland in the years 1926-1932. The involvement of military authorities in this process was primarily taken into consideration. Prometheism was considered as one of the organised concepts of implementing not only political but also information and intelligence activities.

The author defines the place and importance of Prometheism in the activities of Polish military intelligence in the years 1926-1932. He also distinguishes examples of cooperation with the Promethean nations aiming at strengthening the security of the Second Republic. The archival materials collected in the Central Military Archive in Warsaw-Rembertów and the Archives of Modern Records in Warsaw were used to achieve the objective set.

It should be stated that Prometheism was a significant concept within the involvement of military intelligence in strengthening the national security of the Second Polish Republic. It was evidenced by the Polish authorities' cooperation with nations dependent on Soviet activities in the East.

Keywords: Prometheism, security, military intelligence, the Soviet Union

\section{References}

Archival sources

Ideologia walki ciemiężonych przez Rosję narodów zjednoczonych w organizacji „Prometeusz”, CAW, Oddział II SG WP, sygn. I.303.4.5782.

Instrukcja Charlesa Lorence’a [Stanisława Zaćwilichowskiego] dla Stanisława Hempla, posła RP w Teheranie, z dnia 21 października 1930 roku w sprawie współpracy z Komitetem Niepodległości Kaukazu, CAW, Oddział II SG WP, sygn. I.303.4.5463.

List Dżafera Sejdameta do płk. Tadeusza Schaetzla z dnia 24 stycznia 1930 roku o wyniku rozmów z ministrem spraw zagranicznych Ukraińskiej Republiki 
Ludowej, Aleksandrem Szulkinem w sprawie stosunków ukraińsko-tatarskich i uznania niepodległości Krymu, CAW, Oddział II SG WP, sygn. I.303.4.5389. List prof. Romana Smal-Stockiego do kpt. Edmunda Charaszkiewicza w sprawie zorganizowania ukraińskich audycji propagandowych w Radiu Polskim z dnia 24 stycznia 1930 roku, CAW, Oddział II SG WP, sygn. I.303.4.5389.

List szefa Placówki Wywiadowczej Konspol w Konstantynopolu, kpt. Mateusza Iżyckiego, do szefa Oddziału II Sztabu Generalnego, płk. Tadeusza Schaetzla, z dnia 13 września 1927 roku w sprawie paszportów polskich dla Kaukazczyków, AAN, Attachés wojskowi RP przy rządach państw kapitalistycznych 1919-1939, sygn. A-II/33.

Memoriał Zarządu Zrzeszenia Byłych Członków POW - Wschód KN 3 dla Marszałka Józefa Piłsudskiego z dnia 15 stycznia 1932 roku w sprawie współpracy polsko-gruzińskiej [wraz z 13 załącznikami], AAN, Akta Aleksandry i Józefa Piłsudskich, sygn. I/49.

Merytoryczne wyjaśnienia, uzupełniające memoriał Zarządu Zrzeszenia Byłych Członków POW - Wschód KN 3 w sprawie współpracy polsko-gruzińskiej adresowane do Marszałka Józefa Piłsudskiego [luty 1932], AAN, Akta Aleksandry i Józefa Piłsudskich, sygn. I/49.

Notatka kpt. Edmunda Charaszkiewicza dla płk. Tadeusza Schaetzla z zebrania polsko-ukraińskiego w sprawie organizacji audycji radiowych ukraińskich i uregulowania stosunków ukraińsko-kozackich z dnia 28 stycznia 1930 roku, CAW, Oddział II SG WP, sygn. I.303.4.5389.

Notatka wewnętrzna Ekspozytury nr 2 z dnia 6 grudnia 1932 roku w sprawie stypendystów z emigracji prometeuszowskiej, CAW, Oddział II SG WP, sygn. I.303.4.5497.

Notatka wewnętrzna Ekspozytury Nr 2 z konferencji kpt. Edmunda Charaszkiewicza i por. Stanisława Zaćwilichowskiego z Mustafą Czokajewem z dnia 20 lipca 1930 roku w sprawie działalności emigracji turkiestańskiej, CAW, Oddział II SG WP, sygn. I.303.4.5710.

Pismo kierownika Placówki Wywiadowczej L3 w Konstantynopolu do kierownika Referatu B1. Oddziału II Sztabu Generalnego z dnia 26 kwietnia 1929 roku na temat informacji otrzymanych od Dżafera Sejdameta, CAW, Oddział II SG WP, sygn. I.303.4.1996.

Pismo ministra skarbu, Jerzego Zdziechowskiego, do szefa Sztabu Generalnego, gen. bryg. Edmunda Kesslera, z dnia 28 marca 1926 roku w sprawie oficerów gruzińskich, AAN, Ministerstwo Spraw Zagranicznych, sygn. 6687.

Pismo ministra spraw zagranicznych, Aleksandra Skrzyńskiego do Ministra Spraw Wojskowych w sprawie oficerów gruzińskich w Wojsku Polskim z dnia 11 lutego 1926 roku, AAN, Ministerstwo Spraw Zagranicznych, sygn. 6687.

Pismo pracownika konsulatu RP w Pradze, Tadeusza Lubaczewskiego, do szefa Oddziału II Sztabu Generalnego, płk. Tadeusza Schaetzla, z dnia 7 grudnia 
1928 roku w sprawie sytuacji wśród emigracji kozackiej, CAW, Oddział II SG WP, sygn. I.303.4.5430.

Pismo szefa Sztabu Generalnego, gen. bryg. Edmunda Kesslera, do Ministra Skarbu, Jerzego Zdziechowskiego, z dnia 22 marca 1926 roku w sprawie oficerów gruzińskich, AAN, Ministerstwo Spraw Zagranicznych, sygn. 6687.

Porozumienie ukraińsko-tatarskie z dnia 17 grudnia 1929 roku, CAW, Oddział II SG WP, sygn. I.303.4.5460.

Postulaty przedstawione przez stronę polską prezydentowi Ukraińskiej Republiki Ludowej, Andrijowi Liwickiemu i gen. Włodzimierzowi Salskiemu na konferencji dnia 28 VI 1927, CAW, Oddział II SG WP, sygn. I.303.4.5404.

Projekt reformy podstaw współpracy polsko-gruzińskiej uzupełniający memoriał Zarządu Zrzeszenia Byłych Członków POW - Wschód KN 3 adresowany do Marszałka Józefa Piłsudskiego z dnia 16 lutego 1932 roku, AAN, Akta Aleksandry i Józefa Piłsudskich, sygn. I/49.

Protokół z dnia 27 maja 1930 roku z posiedzenia Komitetu Niepodległości Kaukazu w Warszawie z udziałem przedstawicieli strony polskiej, AAN, Ministerstwo Spraw Zagranicznych, sygn. 6690.

Raport Z. Mostowskiego do MSZ z XI 1927, AAN, Ministerstwo Spraw Zagranicznych, sygn. 10218.

Sprawozdanie por. Stanisława Zaćwilichowskiego z dnia 13 sierpnia 1930 roku z podróży do Stambułu, CAW, Oddział II SG WP, sygn. I.303.4.5710.

Wykaz oficerów kontraktowych w Wojsku Polskim: Gruzinów, Azerów i Górali Kaukaskich z dnia 9 grudnia 1927 roku, AAN, Attachés wojskowi RP przy rządach państw kapitalistycznych 1919-1939, sygn. A-II/33.

\section{Published documents}

Bruski, J.J., Pisuliński, J., Polska dyplomacja wobec emigracji ukraińskiej. Nieznana instrukcja ministra Augusta Zalewskiego z 1926 roku, „Studia z Dziejów Rosji i Europy Środkowo-Wschodniej" 1998, vol. 33, s. 161.

Charaszkiewicz, E., Zagadnienie prometejskie (referat uzupełniajacy), 12 luty 1940 r., [in:] Zbiór dokumentów ppłk. Edmunda Charaszkiewicza, study by A. Grzywacz, M. Kwiecień, G. Mazur, Kraków 2000.

Kraj Zakaukaski w relacjach dyplomatów II Rzeczypospolitej, study by A. Furier, Warszawa 1999.

Kwiecień, M., Kilka dokumentów z dziejów ruchu prometejskiego lat drugiej wojny światowej, „Krakowskie Studia z Historii Państwa i Prawa” 2014, vol. 7, nr 2.

Libera, P., Depesze Dżafera Sejdameta do Ligi Narodów i do Marszałka Piłsudskiego w sprawie objęcia przez Polskę mandatu nad Krymem $z$ komentarzem P. Libery, „Nowy Prometeusz” 2012, nr 2. 
Libera, P., Zarys historii ruchu prometejskiego, [in:] II Rzeczpospolita wobec ruchu prometejskiego, t. 4, ed. P. Libera, Warszawa 2013.

Mazur, G., Kwiecień M., Kilka dokumentów z dziejów ruchu prometejskiego w II Rzeczypospolitej, „Czasy Nowożytne” 2002, nr 12.

Pakt nieagresji między Rzeczpospolitą Polską a Związkiem Socjalistycznych Republik Rad, podpisany w Moskwie dnia 25 lipca 1932 roku (Dz.U. 1932, nr 115, poz. 951).

Sprawozdanie kpt. Stefana Nowaczka z wyszkolenia dywersyjnej grupy gruzińskiej [1930], [in:] II Rzeczpospolita wobec ruchu prometejskiego, t. 4, ed. P. Libera, Warszawa 2013.

Wizyta gen. Aleksandra Zachariadze w Warszawie dnia 17 lipca 1929 roku. Wytyczne Gruzińskiej Organizacji Wojskowej, [in:] II Rzeczpospolita wobec ruchu prometejskiego, t. 4, ed. P. Libera, Warszawa 2013.

Współdziałanie rządu polskiego z emigracyjnymi organizacjami antyradzieckimi w latach 1918-1938, study by S. Wroński, „Z dziejów stosunków polsko-radzieckich. Studia i materiały” 1968, vol. 3.

Scientific studies

Bruski, J.J., Między prometeizmem a Realpolitik. II Rzeczpospolita wobec Ukrainy Sowieckiej 1921-1926, Kraków 2010.

Bruski, J.J., $Z$ dziejów akcji prometejskiej. Odnowienie wspótpracy Polski z emigracja ukraińska w 1926 roku, [in:] Naród - państwo - Europa Środkowa w XIX i XX wieku, eds. A. Patek, R. Wojek, Kraków 2006.

Furier, A., Kaukaz w dokumentach polskiej stużby konsularnej z okresu międzywojennego, Szczecin 2019.

Gasimov, Z., Między Warszawą, Paryżem a Stambułem. Myśli o prometeizmie $w$ ideowej przestrzeni międzywojennej Europy, [in:] Ruch prometejski i walka o przebudowę Europy Wschodniej (1918-1940), ed. M. Kornat, Warszawa 2012.

Grzywacz, A., Mazur G., Ruch prometejski w Polsce, „Zeszyty Historyczne” 1994, vol. 110.

Karabin, R., Gruzinssy podchorążowie i oficerowie kontraktowi w Wojsku Polskim 1921-1939, „Pro Georgia” 1994, nr 4.

Karpus, Z., Rezmer W., Mniejszości narodowe i wyznaniowe w siłach zbrojnych Drugiej Rzeczypospolitej 1918-1939, Toruń 2001.

Komar, W., Emigracja kaukaska w ruchu prometejskim okresu międzywojennego, [in:] Kaukaz w stosunkach międzynarodowych. Przeszłość, teraźniejszość, przyszłość, eds. K. Borkowski, P. Olszewski, Piotrków Trybunalski 2008.

Komar, V., Kontseptsiya prometeizmu v polititsi Pol'shchi (1921-1939 pp.), Ivano-Frankivs'k 2011. 
Komar, W., Stosunki polityczne Ukraińców i Tatarów krymskich w okresie międzywojennym, „Nowy Prometeusz” 2012, nr 2.

Kornat, M., Idea prometejska a polska polityka zagraniczna (1921-1939/1940), [in:] Ruch prometejski i walka o przebudowę Europy Wschodniej (1918-1940), ed. M. Kornat, Warszawa 2012.

Kornat, M., Ruch prometejski - ważne doświadczenie polityki zagranicznej II Rzeczypospolitej, „Nowa Europa Wschodnia” 2008, nr 2.

Kornat, M., W kręgu ruchu prometejskiego. Związek Zbliżenia Narodów Odrodzonych (1921-1923) i Instytut Wschodni w Warszawie (1925-1939), „Politeja” 2004, nr 2.

Kowalski, Z., Najliczniejsza mniejszość. Gruzini, Azerowie i inni przedstawiciele narodów Kaukazu w Wojsku Polskim w okresie międzywojennym, [in:] Mniejszości narodowe i wyznaniowe w siłach zbrojnych Drugiej Rzeczypospolitej 1918-1939, ed. Z. Karpus, Torun 2001.

Krawcewicz, A., Ideologiczne podstawy polskiej geopolityki na przykładzie koncepcji prometejskiej, „Zeszyty Naukowe Uniwersytetu Szczecińskiego. Acta Politica" 2014, nr 28.

Krotofil, M., Oficerowie kontraktowi Wojska Polskiego w okresie międzywojennym, „Biuletyn Ukrainoznawczy” 1999, nr 5.

Kruszyński, M., Kaukaz w polityce MSZ - rola i znaczenie Konsulatu Generalnego $R P w$ Tbilisi w okresie międzywojennym, „Nowy Prometeusz” 2012, nr 2.

Landmann, T., Prometeizm jako założenie polityczno-ideologiczne w korespondencji Polskiej Grupy Prometeusza w Londynie w pierwszych latach po II wojnie światowej, „Wschodnioznawstwo” 2018.

Libera, P., Ewolucja ruchu prometejskiego w okresie międzywojennym, [in:] Ruch prometejski i walka o przebudowę Europy Wschodniej (1918-1940), red. M. Kornat, Warszawa 2012.

Libera, P., Orientalistyczne Koło Młodych przy Instytucie Wschodnim w Warszawie (1929-1939), „Nowy Prometeusz” 2018, nr 12.

Libera, P., Polski prometeizm. Jak ewoluowat i jak $z$ nim walczono?, „Pressje” 2010, vol. 22-23.

Maj, I.P., Działalność Instytutu Wschodniego w Warszawie 1926-1939, Warszawa 2007. Materski, W., Gruzini - oficerowie kontraktowi Wojska Polskiego, „Pro Georgia” 2008, nr 16.

Mądzik, M., Z historii politycznych stosunków polsko-gruzińskich w latach 19181921, [in:] Pro Georgia. Prace i materiału do dziejów stosunków gruzińsko-polskich, ed. D. Kolbaja, Warszawa 1991.

Mikulicz, S., Prometeizm w polityce II Rzeczypospolitej, Warszawa 1971.

Pepłoński, A., Wywiad a dyplomacja II Rzeczypospolitej, Toruń 2004.

Pisuliński, J., Centrum Państwowe Ukraińskiej Republiki Ludowej na wychodźstwie w polskiej polityce zagranicznej po 1926 r., „Istorychnyy arkhiv. Naukovi studiyi” 2010, в. 5. 
Pisuliński, J., Prometeizm - problemy i pytania historiograficzne, [in:] Ruch prometejski i walka o przebudowe Europy Wschodniej (1918-1940), ed. M. Kornat, Warszawa 2012.

Pisuliński, J., Ukrainian diaspora in Polish foreign policy in the interwar period, „Nowa Ukraina” 2011, vol. 11.

Potocki, R., Idea restytucji Ukraińskiej Republiki Ludowej (1920-1939), Lublin 1999.

Rogozińska, A., Myśl polityczna obozu piłsudczykowskiego wobec kwestii położenia geopolitycznego i bezpieczeństwa granic II Rzeczpospolitej, „Niepodległośc” 2014, vol. 63.

Światłowski, B., Prometejska racja stanu, „Poliarchia” 2014, nr 2.

Werschler, I., Federalizm i prometeizm w poglądach oraz działalności Tadeusza Hołówki, „Dzieje Najnowsze” 1982, vol. 1-4.

Wiszka, E., Emigracja ukraińska w Polsce 1920-1939, Toruń 2004.

Witak, R., Tajne wojny służb specjalnych II RP. Działalność Ekspozytury nr 2 Oddziału II Sztabu Głównego WP w latach 30. XX w., Łódź 2014.

Wszendyrówny, A., Ekspozytura Nr 2 Oddziału Sztabu Głównego Wojska Polskiego, [in:] Ruch prometejski i walka o przebudowę Europy Wschodniej (19181940), ed. M. Kornat, Warszawa 2012.

Wszendyrówny, A., Prometeizm jako narzędzie polskiej polityki zagranicznej wobec ZSRR, http://www.muzeum-niepodleglosci.home.pl/konferencja/referaty_/23.pdf.

Wyszczelski, L., Rozpruwanie Rosji. Prometeizm - idea i realizacja, Warszawa 2016. Zackiewicz, G., Polska myśl polityczna wobec systemu radzieckiego 1918-1939, Kraków 2004.

Żebrowski, A., Oddział II Sztabu Generalnego/Głównego Wojska Polskiego uczestnikiem wojny informacyjnej na kierunkach Niemcy i Rosja, [in:] Wywiad wojskowy II Rzeczypospolitej, eds. P. Kołakowski, A. Pepłoński, Kraków 2011.

Tomasz Landmann - dr historii, wykładowca na Wydziale Nauk o Bezpieczeństwie w Akademii Wojsk Lądowych im. gen. T. Kościuszki we Wrocławiu. ORCID: 0000-0002-9753-9373 